\title{
Cellular Responses by Low-power He-Ne laser Irradiation on Human Lung Cancer Cells
}

\author{
Chi-Chung Wang ${ }^{1}$, Wei-Chih Chen ${ }^{1}$, Chi-Feng Hung ${ }^{2}$ and Vinchi Wang ${ }^{2,3^{*}}$ \\ ${ }^{1}$ Graduate Institute of Basic Medicine, Fu-Jen Catholic University, Xinzhuang District, New Taipei City, 24205, Taiwan \\ ${ }^{2}$ School of Medicine, College of Medicine, Fu-Jen Catholic University, Xinzhuang District, New Taipei City, 24205, Taiwan \\ ${ }^{3}$ Neurological Center, Cardinal Tien Hospital, Xindian District, New Taipei City, Taiwan
}

*Corresponding author: Vinchi Wang, Neurological Center, Cardinal Tien Hospital 362, Zhongzheng Road, Xindian District, New Taipei City 231, Taiwan, Tel: +886-2-22193391 ext 66672; E-mail: vwneur@yahoo.com.tw

Received date: Apr 22, 2015, Accepted date: June 15, 2015, Publication date: June 19, 2015

Copyright: ( 2015 Wang CC, et al. This is an open-access article distributed under the terms of the Creative Commons Attribution License; which permits unrestricted use; distribution; and reproduction in any medium; provided the original author and source are credited.

\begin{abstract}
Helium-neon ( $\mathrm{He}-\mathrm{Ne}$ ) laser has been used in many clinical fields, and caught our interest on cancer treatment. We conducted the study of He-Ne laser in lung cancer for the sake of the most common cause of cancer deaths worldwide, and up to $50 \%$ of the patients with advanced non-small-cell lung cancers with brain metastases. In this study, we used two human lung cancer cell lines A549, H1299, bronchial epithelial cell line BEAS-2B to detect the effects of He-Ne laser on proliferation and migration capabilities by MTT, trypan blue exclusion and wound healing analysis, followed by Western blot analysis to identify the putative signaling pathway evoked by the He-Ne laser. Low-power He-Ne laser slowed H1299 migration by inhibiting Extracellular signal-regulated protein kinases (ERK) phosphorylation, and decreased A549 cell proliferation via p38 up-regulation. However, He-Ne laser increased NT2 cell proliferation and migration activities through ERK activation. The low-power He-Ne laser had diverse effects on different cells, possibly suppressive effect on malignant cells, but growth provocation on pluripotent cells. We proposed that the low-power He-Ne laser renders a beneficial alternative for cancer treatment and for tissue repair.
\end{abstract}

Keywords: NSCLC; He-Ne laser; Proliferation; Migration; MAPK

\section{Abbreviations:}

ERK: Extracellular Signal-regulated Protein Kinases; JNKs: Jun Nterminal kinases; MAPK: Mitogen-Activated Protein Kinases; PDT: Photodynamic Therapy

\section{Introduction}

Lung cancer is the most common cause of cancer deaths in the world, accounting for $27.19 \%$ of all cancer deaths in the United State of America [1], and in Taiwan the crude death rate gradually increased during the past decade from 2004 to 2013 [2]. No matter by chemotherapy and radiotherapy, unsatisfactory outcomes in lung cancer patients are often attributed to the difficulties for early detection and sometimes to limited interventional feasibility to target the tumour bulk.

In this study we explored the alternative approach for the management of lung cancer. Photodynamic therapy (PDT) has been proposed as a treatment option for the centrally-located early lung cancer at stage 0 (TisN0M0) and stage I (T1NOM0) [3], including the exposure of cells and tissues to a photosensitizing drug followed by irradiation with low-power laser, and was compatible with the absorption spectrum of the photosensitizer drug [4].

Since 1960s, there had been medical applications involving the use of the laser. The low-power laser with output power less than one watt (between 1 and $500 \mathrm{~mW}$ ) [5] will not damage the hydrogen bonds in the tissues but brings about a photochemical effect [6]. Depending on the power density, frequency, wavelengths, irradiation procedures, and the cell types, the low-power laser has evidences to modulate various biological processes in animal models and cell-based interventions [79], the latter including cell proliferation, differentiation, apoptosis, and release of growth factors from cells [10-12].

In addition, it has been applied in treating diseases with limited regeneration and in promoting wound healing [13,14], and some clinical studies had stated the wavelengths most beneficial with red and near infrared ranges (from 630 to $850 \mathrm{~nm}$ ) for the photobiostimulation effects $[15,16]$.

The Helium-neon (He-Ne) laser with wave length of $632.8 \mathrm{~nm}$ is a low-energy laser emitting radiation in the visible light spectrum. He$\mathrm{Ne}$ laser stimulated a number of biological processes, including cell growth, proliferation, and migration [17-19]. Other evidences were also proposed that $\mathrm{He}-\mathrm{Ne}$ laser irradiation affected both bioenergetics and biogenesis of mammalian mitochondria and increase cytokine/ growth factor release [20-22].

However, the mechanisms associated with the photo-modulatory effects of the He-Ne laser remained elusive, as the ill-defined effects of low-power He-Ne laser on cancer cell proliferation and migration, including the lung cancers. Thus, we would like to investigate the mechanisms involved in photostimulatory effects induced by $\mathrm{He}-\mathrm{Ne}$ laser irradiation in lung cancer cells and to evaluate its application in lung cancer treatment.

\section{Materials and Methods}

\section{Cell culture}

Human lung adenocarcinoma cell lines A549 (ATCC ${ }^{\circ}$ access number, CCL-185TM), H1299 (ATCC ${ }^{\circ}$ CRL-5803TM), malignant 
Page 2 of 6

pluripotent human testicular embryonal carcinoma cell NT2 (NTERA-2 cl.D1, ATCC ${ }^{\circ}$ CRL-1973TM), and the primary immortalized bronchial epithelial cells, BEAS2B (ATCC CRL-9609TM) were all maintained at $37^{\circ} \mathrm{C}$ in a humidified atmosphere containing $5 \% \mathrm{CO}_{2}$. Cells were cultured in DMEM or RPMI 1640 medium (Life Technologies, Rockville, MD, USA) supplemented with $10 \%$ heat-inactivated fetal bovine serum (FBS; Life Technologies) and 1\% penicillin-streptomycin (Life Technologies).

\section{Low-power He-Ne laser irradiation}

The experiments were conducted with a low-power He-Ne laser (Model JY-ILIB-5, Bio-Resonancehuman energy Corp, Taipei, Taiwan), which emits $632.8 \mathrm{~nm}$ wavelength with an output of $4.0 \mathrm{~mW}$ for $0,5,10,15$ and 30 minutes. Dose effect was determined by the treating durations. The cultured cells were harvested from the culture Petri dishes for $24 \mathrm{hr}$ incubation initially, and then rinsed once by phosphate-buffered saline (PBS) before irradiation with $1 \mathrm{ml}$ retained in the microtubes. The electrode tip of He-Ne laser was gently agitated below the PBS surface with emitted laser to contact cells directly. Throughout each experiment all dishes (including controls) were maintained in PBS at room temperature. All irradiation experiments were at least repeated in triplicates.

\section{Cell viability assay}

The cells were seeded onto 96-well plates at 4,000 cells per well in culture media $(100 \mu \mathrm{l})$. After culturing for various durations, cell numbers were measured by thiazolyl blue tetrazolium bromide (synonym as methylthiazolyldiphenyl-tetrazolium bromide, MTT) assay according to the protocol (Sigma-Aldrich Corp., St. Louis, MO, USA). In briefly, $10 \mu \mathrm{l}$ of the MTT solution $(5 \mathrm{mg} / \mathrm{ml})$ were added to each well and the cells were cultured for another $4 \mathrm{hr}$ at $37^{\circ} \mathrm{C}$. One hundred microliters of $0.04 \mathrm{~N} \mathrm{HCl}$ in isopropanol were then added to each well, and mixed vigorously to solubilize colored crystals produced within the cells. The absorbance value at $570 \mathrm{~nm}$ was measured by a multi-well scanning spectrophotometer.

\section{Growth curve determination}

The effect of He-Ne laser irradiation on cellular proliferation was assessed by visually counting the number of cells in conjunction with trypan blue exclusion. Cells were seeded with a density of $1-4 \times 10^{5}$ cells/well and were incubated overnight. Then cells were irradiated with $4.0 \mathrm{~mW}$ He-Ne laser radiation for various time courses and incubated for 1-3 days. The cells were then washed with PBS and trypsinized, followed by mixing with equal volume of trypan blue dye. Finally, the number of living cells was counted with a hematocytometer chamber.

\section{Cell migration assay}

The cells were seeded into $6 \mathrm{~cm}$ culture dishes at a density of $2.5 \times 10^{5}$ cells and cultured in medium containing $10 \%$ FBS for $24 \mathrm{hr}$. Then the nearly confluent cell monolayer was carefully scratched using a $10 \mu$ pipette tip. Any cellular debris was removed by washing with PBS. After making wounds, the cultures were incubated at $37^{\circ} \mathrm{C}$ and we took pictures immediately ( $\mathrm{t}=0), 4,8$ and $12 \mathrm{hrs}$ later. The number of cells migrating into the cell-free zone was counted under a light microscope. The experiments were performed in triplicate.

\section{Western blot analysis}

Western blot analysis was used to examine the expression levels of the affected protein after low-power He-Ne laser irradiation in various cell lines. The details of these procedures were described previously [23]. The specific primary antibodies for anti-phospho-ERK1/2 (T202/ Y204, \#9101, Cell Signaling Technology), anti-total ERK2 (\#9102), and anti-total p38 MAPK (mitogen-activated protein kinases) (\#9212), all from Cell Signaling Technology, were applied for the serial investigations, with $\alpha$-tubulin used as an internal control.

After incubation with the primary antibodies, membranes were washed three times with TBST (Tris-buffered saline and Tween 20) solution, followed by incubation with horseradish peroxidase (HRP)conjugated secondary antibodies (Santa Cruz Biotechnology, Santa Cruz, CA, USA) and detection using an enhanced chemiluminescence detection system (ECL, GE Healthcare, Piscataway, NJ, USA).

\section{Statistical analysis}

All experiments were performed in triplicate and analyzed by ANOVA (Excel, Microsoft). All statistical tests were two-sided, and P value $<0.05$ was considered statistically significant. Where appropriate, the data are presented as the mean \pm standard deviation.

\section{Ethical declaration}

This is a cell-based study, without laser use for the animals and humans. Thus our work did not have the revisions by the Institutional Animal Care and Use Committee (IACUC) and Institutional Review Board (IRB).

\section{Results}

\section{Low-power He-Ne laser irradiation significantly slowed A549 cell proliferation}

At first we would like to explore the effect of the low-power He-Ne laser on the cell growth by the proliferation and viability assays. The primary immortalized bronchial epithelial cell, BEAS2B, and lung cancer cells, A549 and H1299 cells, were applied to assess the effects of $\mathrm{He}-\mathrm{Ne}$ laser irradiation on cell growth by trypan blue exclusion assay (Figure 1).

The low-power He-Ne laser irradiation lacked the effect on BEAS2B cells (Figure 1A). However, no matter long- (30 min) or short-treating ( $5 \mathrm{~min}$ ) duration of the laser exposure applied with $4 \mathrm{~mW}$ He-Ne laser irradiation, the cell numbers of A549 cells decreased significantly after $48 \mathrm{hr}$, as compared with the ones without treatment ( $0 \mathrm{~min}, \mathrm{P}<0.05$; Figure 1B).

For the study of H1299 cells, there was no significant change of the cell numbers after low-power He-Ne laser exposures (Figure 1C). On MTT assay for the cell viabilities of these cell lines after laser emission, as shown in Figure 2A and 2C, long exposure time (30 min) of lowpower He-Ne laser irradiation could lead to a decrease in cell viability of both BEAS2B and H1299 cells, but not for the cells on the shorter time treatment.

In contrast, both short and long exposure of low-power He-Ne laser irradiation resulted in decreasing cell viabilities after 2 days in A549 cells (Figure $2 \mathrm{~B}, \mathrm{P}<0.05$ ). This result was consistent with the trypan blue exclusion data. 
Citation: Wang CC, Chen WC, Hung CF, Wang V (2015) Cellular Responses by Low-power He-Ne laser Irradiation on Human Lung Cancer Cells. J Nucl Med Radiat Ther 6: 234. doi:10.4172/2155-9619.1000234

Page 3 of 6

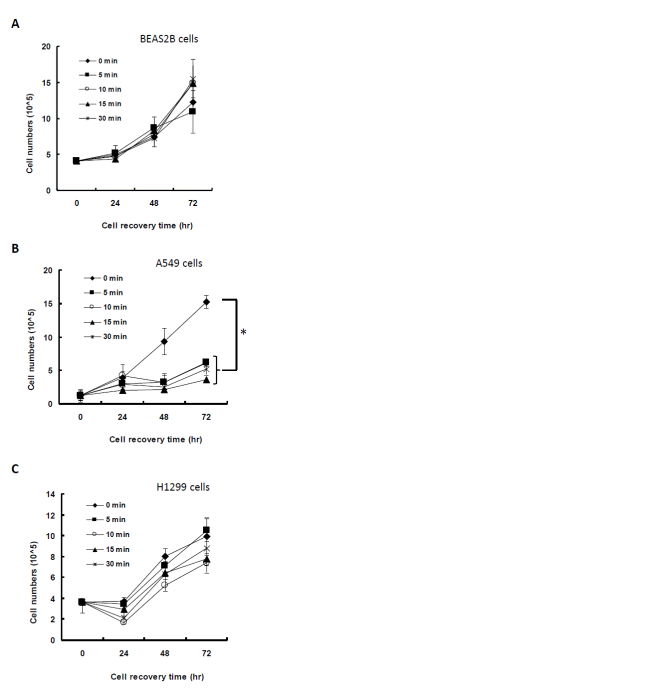

Figure 1: The effects of low-power He-Ne laser irradiation on cell growth were assessed by trypan blue exclusion assay. (A) BEAS2B, (B) A549, and (C) H1299 cells were seeded with a density of $1-4 \times 10^{5}$ cells per well and were irradiated with $4.0 \mathrm{~mW}$ He-Ne laser radiations for various time courses and incubated for 1-3 days. Three independent experiments were performed. The data are presented as the mean $\pm \mathrm{SD} .{ }^{\star} \mathrm{P}<0.05$ compared with the untreated control group (0 min).

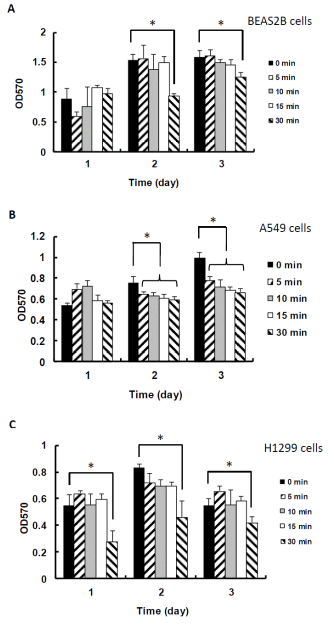

Figure 2: The effects of low-power He-Ne laser irradiation on cell viability were determined by MTT assay. (A) BEAS2B, (B) A549, and (C) H1299 cells were seeded with 4,000 cells per well and were irradiated with $4.0 \mathrm{~mW}$ He-Ne laser radiations for various time courses and incubated for 1-3 days. All data are shown as the mean $\pm \mathrm{SD}$ of the results from three independent experiments. ${ }^{*} \mathrm{P}<0.05$ compared with the untreated control group.

\section{Low-power He-Ne laser irradiation significantly suppressed H1299 cell mobility}

Besides cell proliferation and viability, we investigated cell mobility analyzed by the scratch wound healing assay (Figure 3 ), which implies the reactions between tumor cells and extracellular matrix while invasion. The low-power He-Ne laser irradiation had no effects on A549 cell mobility (Figure 3A). But lower migration capability of H1299 cells occurred after low-power He-Ne laser irradiation with longer treatment time, more prominent after harvesting for 8 and 12 hrs as compared with that of the untreated control group (Figure 3B, $\mathrm{P}<0.05$ ). Although less viability changes on laser treatment in above experiment, H1299 cells had more suppression of cell mobility after long-duration laser irradiation.
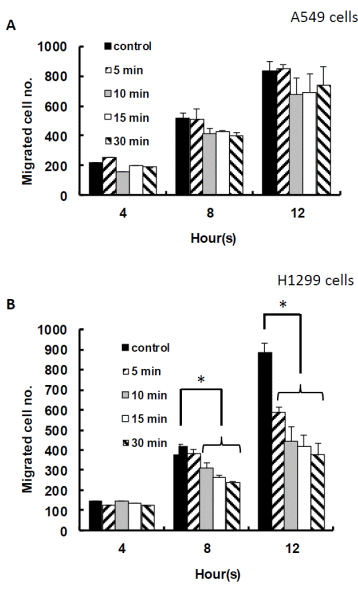

Figure 3: The effects of low-power He-Ne laser irradiation on cell mobility were assessed by wound healing assay. The numbers of (A) A549 and (B) H1299 cells migrated into the cell-free zone after 4.0 $\mathrm{mW} \mathrm{He}-\mathrm{Ne}$ laser irradiations for various time courses were evaluated at indicated time intervals after scratch wounding. The triplicated experiments were conducted independently and the data shown as the mean $\pm \mathrm{SD} .{ }^{\star} \mathrm{P}<0.05$, compared with the untreated control group.

\section{Low-power He-Ne laser irradiation increased p38 expression levels in A549 cells and decreased the phosphorylation of ERK in $\mathrm{H} 1299$ cells}

As already known, mitogen-activated protein kinases (MAPKs) play critical roles in cell proliferation, migration, oncogenesis, differentiation, inflammation and stress responses [24,25]. Therefore we further investigated the intracellular signaling molecules for the behavioral changes of the A549 and H1299 cells. Laser-irradiated cells followed by harvest for $48 \mathrm{hr}$ were then subjected to Western blot assay.

In A549 cells, the expression levels of p38 significantly increased 2.5 to 5.4 folds after low-power He-Ne laser irradiation (Figure $4 \mathrm{~A}$ ). In H1299 cells, the longer exposure (durations, 15 and $30 \mathrm{~min}$ ) on lowpower He-Ne laser irradiation decreased the phosphorylated ERK, but no significant changes in the expression levels of p38 (Figure 4B). 
Page 4 of 6

These results may suggest different molecular mechanisms after lowpower He-Ne laser irradiation in these two lung cancer cells.

A
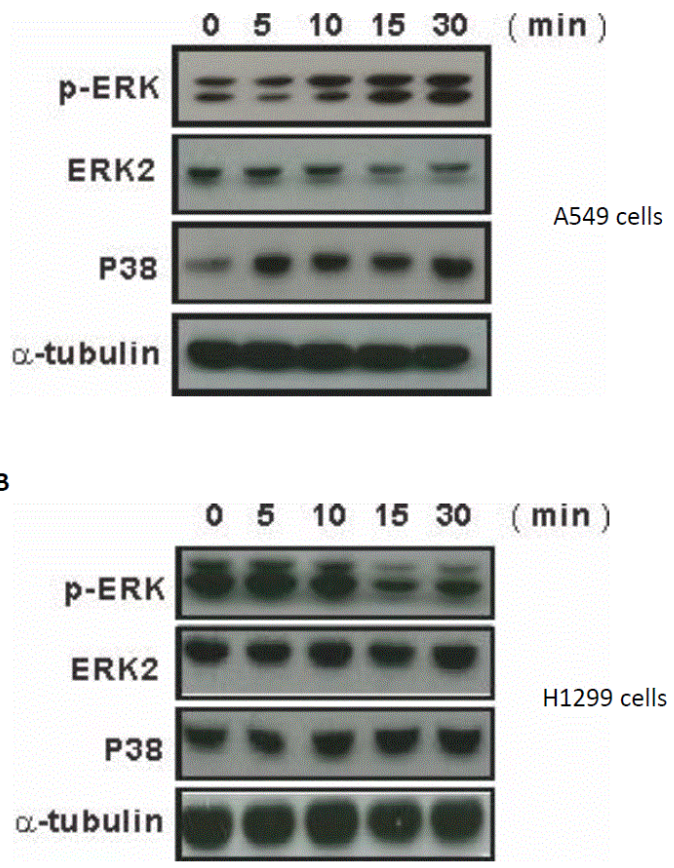

Figure 4: Immunoblot analysis showed the effects of low-power HeNe laser irradiation on MAPK expression levels. The expression levels of p-ERK, ERK2, and p38 proteins in the (A) A549 and (B) H1299 cells that were irradiated with $4.0 \mathrm{~mW} \mathrm{He}-\mathrm{Ne}$ laser irradiations for various time courses were determined by Western blot analysis after recovery for $48 \mathrm{hr}$. The $\alpha$-tubulin served as an internal control.

As a comparison, we chose another cell line, pluripotent human testicular embryonic carcinoma NT2 cells isolated from lung metastatic lesions, to check whether the above phenomena were cell type-specific on laser irradiation. NT2 cells were irradiated by $4 \mathrm{~mW}$ He-Ne laser for different durations, and cell proliferation activity was determined by trypan blue exclusion and MTT assays.

No matter what the treatment durations were, the slopes of cell growth curves of NT2 irradiated with low-power He-Ne laser increased evidently after 48 and $72 \mathrm{hrs}$, as compared with those of the untreated control group (Supplementary Figure 1A).

In addition, the result of MTT assay also revealed higher cell viability after 30-min exposure of low-power He-Ne laser irradiated group than in the control group on day 2 and day 3 (Supplementary Figure $1 \mathrm{~B}, \mathrm{P}<0.05$ ).

Moreover, the migration capacity of NT2 cells also increased by $38 \%$ to $56 \%$ after the long exposure (15-30 $\mathrm{min}$ ) of low-power He-Ne laser irradiation (Supplementary Figure 1C, $\mathrm{P}<0.05$ ). Furthermore, elevated expression of phosphorylated ERK occurred after the lowpower He-Ne laser irradiation, no matter the irradiation time of 5, 10, 15 and $30 \mathrm{~min}$ (Supplementary Figure 1D).

\section{Discussion}

Low-power laser irradiation has been applied in wound healing, adjuvant treatment of spinal cord injury, and mucositis caused by cancer therapies $[13,26]$. But this study stated the direct effects on lung cancer cells by low-power He-Ne laser irradiation. Low-power He-Ne laser irradiation significantly decreased proliferation of A549 cells by increasing expression level of p38 protein. In addition, it also suppressed H1299 cell migration capability via lowering phosphorylation of ERK. To our knowledge, this is the first study to demonstrate that the low-power $\mathrm{He}-\mathrm{Ne}$ laser irradiation could suppress cell proliferation and migration through the MAPK alterations in lung cancers.

However, the low-power He-Ne laser irradiation on the pluripotent NT2 cells had the contrary results. It increased NT-2 cell proliferation and migration via ERK activation. Low-power laser irradiations have been demonstrated to promote proliferation in several fairlydifferentiated cell types, including endothelial cells, lymphocytes, fibroblasts, melanocytes, and HeLa cells [19,27-31]. Mechanisms for the mitogenic effects of low-power laser irradiation have been stated, including MAPK pathway [32]. It has been proposed that laser induced dimerization of some ligand-free receptors, and then autophosphorylation resulting in the downstream effects [9] such as the increased concentration of intracellular calcium and activated calcium channels $[33,34]$. Moreover, it has been shown that low-power laser energy would result in increase in reactive oxygen species, adenosine triphosphate or cyclic AMP via energy absorbed by mitochondrial respiratory chain components $[35,36]$.

In mammalian cells, there are at least three MAPK cascades that are activated by different environmental stresses. For example, p38 and the Jun N-terminal kinases (JNKs) are strongly activated by stress signals such as high osmolality, pro-inflammatory cytokines, heat shock, and UV irradiation [37,38]. The ERK was vital in growth factor-induced mitogenesis, cell transformation, and differentiation [39]. A known result stated that low-power He-Ne laser irradiation provoked proliferation of melanoma cells through the mitochondrial pathway, which subsequently activates JNK and increases the transcriptional activity of activator protein-1, AP-1 [40]. In skeletal muscle cell regeneration, low-power $\mathrm{He}-\mathrm{Ne}$ laser irradiation could activate ERK but with no effect on JNK or p38 [41].

As a comparison in the present study, the low-power laser irradiation promoted NT2 cell proliferation with ERK activation. Interestingly, low-power laser irradiation had no effect on H1299 cell or even decreased A549 cell proliferation through up-regulation of p38 protein kinase in this study. The negative p38 signaling effect on cell proliferation and the underlying molecular mechanisms had been documented [42]. Some studies indicated that p38 could mediate either DNA-damage-induced apoptosis or oncogene-induced senescence through activating p53, a downstream effector of p38 $[43,44]$. Therefore, p38/p53 axis would be supposed to conduct the proliferation inhibition of A549 cells, which contain wild typed p53, after low-power He-Ne laser exposure. However, p53-null H1299 cell line lost this effect on cell proliferation. The role of p53 on lung cancer cells after laser treatment needs more work to dissect.

Besides the cell proliferation, differentiation, inflammation, oncogenesis, and stress response, there was also evidence about MAPK family contributing to cell migration [24]. On using the specific inhibitors for the ERK pathway, migration of different cell types in response to growth factors, cell matrix proteins, and other stimuli 
Page 5 of 6

became inhibited [25]. Our results showed that low-power laser irradiation could suppress H1299 cell migration abilities via inhibiting ERK activation. In contrast, the NT2 cell told a different story about the enhanced cell migration through increase in ERK phosphorylation. Direct activation of the downstream signaling substrates or indirect responses via other signal pathways activated after low-power laser irradiation still needs to be identified. For clinical interest, migration changes after low-power He-Ne laser irradiation may be a critical issue for dealing with metastasis of human lung cancers. For instance, it has been demonstrated that the combination of vascular endothelial growth factor inhibitors could improve the therapeutic efficacy of PDT [45]. Therefore, the combination of PDT using low-power He-Ne laser irradiation and molecule-targeted agents may become new clinical strategies or treatment options for patients with lung cancers.

Some limitations existed in our study. First, in this cell-based study the treatment device of the laser application was not the clinical investigating route. Laser energy may activate the blood cells or degrade the molecules in blood streams resulting in various cell responses, and in a more diverse way from our cell model. Second, the heat production caused by the laser may be a puzzling issue on conducting our bench study, especially while the longer irradiating duration. We monitored the temperature of the laminar hood but not the one of the culture dishes during the laser treatment. Third, we did not test other cancer cell lines of different tissue origins, or the application of the pharmacological inhibitors for the signal pathways in this study. It was mainly attributed to the limited financial support. Fourth, we did not administrate the chemotherapeutic agents concurrently with the laser treatment in this study for the possible synergic or additive effects. Although someone may wonder the palliative role of low-level He-Ne laser in cancer treatment, it is worthy to conduct the clinical application of the laser on chemotherapy for patients with lung cancers.

In conclusion, we stated that the low-power He-Ne laser irradiation inhibits lung cancer A549 cell proliferation and suppresses H1299 cell migration through p38 protein up-regulation and ERK phosphorylation reduction, respectively. He-Ne laser may induce different effects on lung cancer cells with diverse genetic background. In addition, the low-power $\mathrm{He}-\mathrm{Ne}$ laser irradiation promotes proliferation and migration capabilities of human NT2 cells through ERK activation. All these results suggest that the low-power He-Ne laser irradiation may have various effects on cancers, possibly related to the cell types. Catheter-assisted laser transmission may emerge the novel strategies in cancer therapy, especially the He-Ne laser.

\section{Acknowledgments}

This work was supported by the grant from the Cardinal Tien Hospital, Taipei, Taiwan (700192) and in part by the grants from the National Science Council (NSC), Taiwan (NSC99-2628-B-030-002MY3, NSC101-2313-B-030-005). We also thank the Bio-Resonance human energy Ltd Corp for providing the instrument of the lowpower He-Ne laser for this study.

\section{Conflict of Interests}

The authors declare that there is no conflict of interests regarding the publication of this paper.

\section{References}

1. Siegel R, Ma J, Zou Z, Jemal A (2014) Cancer statistics, 2014. CA Cancer J Clin 64: 9-29.

2. http://www.hpa.gov.tw/BHPNet/Web/service/tabbarwithnojava.aspx? $\mathrm{id}=4$.

3. Dougherty TJ, Gomer CJ, Henderson BW, Jori G, Kessel D, et al. (1998) Photodynamic therapy. J Natl Cancer Inst 90: 889-905.

4. Usuda J, Kato H, Okunaka T, Furukawa K, Tsutsui H, et al. (2006) Photodynamic therapy (PDT) for lung cancers. J Thorac Oncol 1: 489-493.

5. Walsh LJ (1997) The current status of low level laser therapy in dentistry. Part 1. Soft tissue applications. Aust Dent J 42: 247-254.

6. Babapour R, Glassberg E, Lask GP (1995) Low-energy laser systems. Clin Dermatol 13: 87-90.

7. Meyers AD, Joyce J, Cohen JJ (1987) Effects of low-watt helium neon laser radiation on human lymphocyte cultures. Lasers Surg Med 6: 540-542.

8. Oron U, Yaakobi T, Oron A, Mordechovitz D, Shofti R, et al. (2001) Low-energy laser irradiation reduces formation of scar tissue after myocardial infarction in rats and dogs. Circulation 103: 296-301.

9. Karu T (1999) Primary and secondary mechanisms of action of visible to near-IR radiation on cells. J Photochem Photobiol B 49: 1-17.

10. Ben-Dov N, Shefer G, Irintchev A, Wernig A, Oron U, et al. (1999) Lowenergy laser irradiation affects satellite cell proliferation and differentiation in vitro. Biochim Biophys Acta 1448: 372-380.

11. Wang F, Chen TS, Xing D, Wang JJ, Wu YX (2005) Measuring dynamics of caspase-3 activity in living cells using FRET technique during apoptosis induced by high fluence low-power laser irradiation. Lasers Surg Med 36: 2-7.

12. Sommer AP, Pinheiro AL, Mester AR, Franke RP, Whelan HT (2001) Biostimulatory windows in low intensity laser activation: lasers, scanners and NASA's light-emitting diode array system. J Clin Laser Med Surg 19: 29-33.

13. Khadra M, Kasem N, Haanaes HR, Ellingsen JE, Lyngstadaas SP (2004) Enhancement of bone formation in rat calvarial bone defects using lowlevel laser therapy. Oral Surg Oral Med Oral Pathol Oral Radiol Endod 97: 693-700.

14. Ribeiro MS, Da Silva Dde F, De Araújo CE, De Oliveira SF, Pelegrini CM, et al. (2004) Effects of low-intensity polarized visible laser radiation on skin burns: a light microscopy study. J Clin Laser Med Surg 22: 59-66.

15. Anders JJ, Borke RC, Woolery SK, Van de Merwe WP (1993) Low power laser irradiation alters the rate of regeneration of the rat facial nerve. Lasers Surg Med 13: 72-82.

16. Mochizuki-Oda N, Kataoka Y, Cui Y, Yamada H, Heya M, et al. (2002) Effects of near infrared irradiation on adenosine triphosphate and adenosine diphosphate contents of rat brain tissue. Neurosci Lett 323: 207-210.

17. Smol'yaninova NK, Karu TI, Fedoseeva GE, Zelenin AV (1991) Effects of He-Ne laser irradiation on chromatin properties and synthesis of nucleic acids in human peripheral blood lymphocytes. Biomed Sci 2: 121-126.

18. Liao X, Xie GH, Liu HW, Cheng B, Li SH, et al. (2014) Helium-neon laser irradiation promotes the proliferation ad migration of human epidermal stem cells in vitro: proposed mechanism for enhanced wound reepithelialization. Photomed Laser Surg 32: 219-225.

19. Yu HS, Wu CS, Yu CL, Kao YH, Chiou MH (2003) Helium-neon laser irradiation stimulates migration and proliferation in melanocytes and induces repigmentation in segmental-type vitiligo. J Invest Dermatol 120: 56-64.

20. Greco M, Vacca RA, Moro L, Perlino E, Petragallo VA, et al. (2001) Helium-Neon laser irradiation of hepatocytes can trigger increase of the mitochondrial membrane potential and can stimulate $\mathrm{c}$-fos expression in a Ca2+-dependent manner. Lasers Surg Med 29: 433-441. 
Citation: Wang CC, Chen WC, Hung CF, Wang V (2015) Cellular Responses by Low-power He-Ne laser Irradiation on Human Lung Cancer Cells. J Nucl Med Radiat Ther 6: 234. doi:10.4172/2155-9619.1000234

Page 6 of 6

21. Hu WP, Wang JJ, Yu CL, Lan CC, Chen GS, et al. (2007) Helium-neon laser irradiation stimulates cell proliferation through photostimulatory effects in mitochondria. J Invest Dermatol 127: 2048-2057.

22. Safavi SM, Kazemi B, Esmaeili M, Fallah A, Modarresi A, et al. (2008) Effects of low-level He-Ne laser irradiation on the gene expression of IL-1beta, TNF-alpha, IFN-gamma, TGF-beta, bFGF, and PDGF in rat's gingiva. Lasers Med Sci 23: 331-335.

23. Tsai MF, Wang CC, Chang GC, Chen CY, Chen HY, et al. (2006) A new tumor suppressor DnaJ-like heat shock protein, HLJ, and survival of patients with non-small-cell lung carcinoma. J Natl Cancer Inst 98: 825-838.

24. Johnson GL, Lapadat R (2002) Mitogen-activated protein kinase pathways mediated by ERK, JNK, and p38 protein kinases. Science 298: 1911-1912.

25. Huang C, Jacobson K, Schaller MD (2004) MAP kinases and cell migration. J Cell Sci 117: 4619-4628.

26. Arun Maiya G, Sagar MS, Fernandes D (2006) Effect of low level heliumneon $(\mathrm{He}-\mathrm{Ne})$ laser therapy in the prevention \& treatment of radiation induced mucositis in head \& neck cancer patients. Indian J Med Res 124 399-402.

27. Kipshidze N, Keelan MH Jr, Nikolaychik V (1996) Impact of red laser light on restenosis. Vascular Brachytherapy. The Netherlands, Nucletron BV, 165-175.

28. Agaiby AD, Ghali LR, Wilson R, Dyson M (2000) Laser modulation of angiogenic factor production by T-lymphocytes. Lasers Surg Med 26: 357-363.

29. Esmaeelinejad M, Bayat M, Darbandi H, Bayat M, Mosaffa N (2014) The effects of low-level laser irradiation on cellular viability and proliferation of human skin fibroblasts cultured in high glucose mediums. Lasers Med Sci 29: 121-129.

30. Lubart R, Wollman Y, Friedmann H, Rochkind S, Laulicht I (1992) Effects of visible and near-infrared lasers on cell cultures. J Photochem Photobiol B 12: 305-310.

31. Zhang J, Xing D, Gao X (2008) Low-power laser irradiation activates Src tyrosine kinase through reactive oxygen species-mediated signaling pathway. J Cell Physiol 217: 518-528.

32. Gao X, Xing D (2009) Molecular mechanisms of cell proliferation induced by low power laser irradiation. J Biomed Sci 16: 4.

33. Breitbart H, Levinshal T, Cohen N, Friedmann H, Lubart R (1996) Changes in calcium transport in mammalian sperm mitochondria and plasma membrane irradiated at $633 \mathrm{~nm}$ (HeNe laser). J Photochem Photobiol B 34: 117-121.

34. Duan R, Liu TC, Li Y, Guo H, Yao LB (2001) Signal transduction pathways involved in low intensity He-Ne laser-induced respiratory burst in bovine neutrophils: a potential mechanism of low intensity laser biostimulation. Lasers Surg Med 29: 174-178.

35. Tuby H, Maltz L, Oron U (2007) Low-level laser irradiation (LLLI) promotes proliferation of mesenchymal and cardiac stem cells in culture. Lasers Surg Med 39: 373-378.

36. Gavish L, Asher Y, Becker Y, Kleinman Y (2004) Low level laser irradiation stimulates mitochondrial membrane potential and disperses subnuclear promyelocytic leukemia protein. Lasers Surg Med 35: 369-376.

37. Minden A, Karin M (1997) Regulation and function of the JNK subgroup of MAP kinases. Biochim Biophys Acta 1333: F85-104.

38. Robinson MJ, Cobb MH (1997) Mitogen-activated protein kinase pathways. Curr Opin Cell Biol 9: 180-186.

39. Osaki LH, Gama P (2013) MAPKs and Signal Transduction in the Control of Gastrointestinal Epithelial Cell Proliferation and Differentiation. Int J Mol Sci 14: 10143-10161.

40. Hu WP, Wang JJ, Yu CL, Lan CC, Chen GS, et al. (2007) Helium-neon laser irradiation stimulates cell proliferation through photostimulatory effects in mitochondria. J Invest Dermatol 127: 2048-2057.

41. Shefer G, Oron U, Irintchev A, Wernig A, Halevy O (2001) Skeletal muscle cell activation by low-energy laser irradiation: a role for the MAPK/ERK pathway. J Cell Physiol 187: 73-80.

42. Bulavin DV, Fornace AJ Jr (2004) p38 MAP kinase's emerging role as a tumor suppressor. Adv Cancer Res 92: 95-118.

43. Sun P, Yoshizuka N, New L, Moser BA, Li Y, et al. (2007) PRAK is essential for ras-induced senescence and tumor suppression. Cell 128: 295-308.

44. Cuadrado A, Lafarga V, Cheung PC, Dolado I, Llanos S, et al. (2007) A new p38 MAP kinase-regulated transcriptional coactivator that stimulates p53-dependent apoptosis. EMBO J 26: 2115-2126.

45. Ferrario A, Chantrain CF, von Tiehl K, Buckley S, Rucker N, et al. (2004) The matrix metalloproteinase inhibitor prinomastat enhances photodynamic therapy responsiveness. Cancer Res 64: 2328-2332. 